\title{
Measuring Economic, Social and Environmental Wellbeing of Asian Economies
}

\author{
Mowshumi Sharmin ( $\nabla$ mowshumi405@gmail.com) \\ Bangladesh Institute of Governance and Management (BIGM) https://orcid.org/0000-0002-5988-4459 \\ Sima Rani Dey \\ Bangladesh Institute of Governance and Management (BIGM) \\ Tariqul Islam \\ University of Nottingham
}

\section{Research Article}

Keywords: CO2 emission, Urbanization, Environmental wellbeing, Life expectancy, EKC hypothesis

Posted Date: May 28th, 2021

DOI: https://doi.org/10.21203/rs.3.rs-488388/v1

License: @ (i) This work is licensed under a Creative Commons Attribution 4.0 International License. Read Full License

Version of Record: A version of this preprint was published at Environmental Science and Pollution Research on October 25th, 2021. See the published version at https://doi.org/10.1007/s11356-021-16999-1. 


\section{Abstract}

This study aims to address the economic, social and environmental wellbeing issues simultaneously by measuring the carbon intensity of wellbeing (CIWB) of Asian economies employing Prais-Winsten and pooled OLS estimator. The measure of carbon intensity of wellbeing (CIWB) is made taking into account a ratio of the two indicators- $\mathrm{CO}_{2}$ emissions per capita and life expectancy at birth. There is paucity of studies that concentrate on human and social wellbeing indicators (i.e., water, sanitation, life expectancy) together applying Environmental Kuznets Curve (EKC) hypothesis. Therefore, we have also investigated the EKC hypothesis as this theory hypothesizes the link involving human and environmental wellbeing and development. The findings utilizing the two econometric techniques indicate that in both the estimation models urban population access to an improved water source and total population access to improved water source has consistently negative and significant effects on CIWB. The fertility rate and prevalence of HIV poses no threat to CIWB. These findings demonstrate that social and human wellbeing indicators of the Asian economies are sustainable to this moment as they are lowering CIWB which is desirable. Contrary, GDP per capita, exports as a percent of GDP and urban population have a significant and positive impact on CIWB which pose a challenge for the sustainability issue. We also have found the existence of EKC hypothesis indicating environmental quality will increase past a turning point. The findings of the paper are well matched with the view of 'Economic and ecological modernization' theory and 'human ecology' theory.

JEL Classification: Q54; Q56; R11

\section{Introduction}

Over the last few decades, wellbeing study has acknowledged greater attention as a source of good or quality life (Summers et al. 2014; 2017). While wellbeing indicators are over and over again related to economic and social policies, and environmental development issues are lagging behind addressing the wellbeing indices even though the environment plays a crucial role in the sustainability and quality of wellbeing (Wainger \& Price, 2004; Smith et al. 2013). Measuring environmental issues on sustainability and their influence on economic, social and human wellbeing becomes clear, particularly while considering both economic growth and quality life together (Jordan et al., 2010). Usually, wellbeing has multidimensional aspects and can be seen as subjective and objective wellbeing. If we define subjective wellbeing, it is often based on human perception, therefore, not directly measurable (Sirgy, 2012). Conversely, objective wellbeing takes account of fundamental economic, social and environmental essentials, therefore, directly measurable (Parris \& Kates, 2003; Talberth et al., 2007). This study aims to incorporate the economic, social, and environmental indicators to measure wellbeing in the context of the sustainable development perspective in an Asian context.

How to ensure the human wellbeing exclusive of environmental degradation remains, an essential inquiry for sustainability? Sustainable development is termed as satisfying human needs without compromising natural and social capital. Therefore, the goal of sustainability is to achieve wellbeing by preserving the natural environment. There are different schools of thought in environmental sociology regarding the interactions between economic growth, degradation of the environment, and wellbeing. Modernization theories, including 'economic and ecological modernization', are in favor of the positive role of economic growth in achieving sustainability and wellbeing (Knight \& Rosa, 2011; York et al., 2003). On the other hand, the 'treadmills of production' theory postulates that, rapid economic development and growth led to a huge demand for energy consumption, which negatively impacted the environment (Knight \& Rosa, 2011; York et al., 2003). The 'human ecology' theory encompasses a wider perspective and views of wellbeing, including health and climate conditions (Bubolz \& Sontag, 2008; Dietz, Rosa, \& York, 2009). This study addresses which of the prevailing theories are appropriate for the Asian economy as a whole, taking some indicators of choice that proxy for the economic, social and environmental wellbeing that ultimately ensures human wellbeing.

As a wellbeing indicator, life expectancy is an inclusive evidence of individual wellbeing and happiness that embraces the usual standard of livelihood, physical state, mental contour, societal ambiance, ecological atmosphere and even the political structure (D'Albis \& Bonnet, 2018; Hill \& Jorgenson, 2018). Therefore, it is crucial to investigate the improvement of countrywide indices while measuring economic, social and human wellbeings. These measurements are interrelated, predominantly as civilization progress towards the postindustrial knowledge and information era where economic achievement greatly relies on investment in human competency improvement. Urbanization is a universal phenomenon though it has a diverse impact in different contexts as a social wellbeing indicator. Urbanization development focused on human and environmental concerns is an essential sustainable development issue and Sustainable Development Goals (SDGs) have a specific goal regarding the sustainability of cities (Sachs, 2015). It is also an integral element of human-induced land use transformation and therefore, this issue needed to be reflected while modeling regional climate issues (Hu et al., 2015).

As a matter of fact, the studies related to $\mathrm{CO}_{2}$ emissions, development, and wellbeing could be biased if the analysis is done by overlooking the regional disparities, combining all nations of the world in a common sample (A. Jorgenson et al., 2012; A. K. Jorgenson \& Clark, 2013). In this context, we examine the relationships between environmental, economic, and social wellbeing indicators for all Asian countries to 
eliminate regional bias addressing the key issues of sustainable environmental development. In the present study a ratio term between per capita $\mathrm{CO}_{2}$ emission and average life expectancy at birth as a wellbeing indicator is used. GDP per capita and export to capture the economic development aspect is incorporated. Urbanization, along with other urban and human wellbeing attributes (i.e., water, sanitation, fertility rate, prevalence of HIV) are factored into the analysis to represent social indicators. All these mentioned indicators are incorporated to analyze the impact of economic, social, and environmetal wellbeing focusing on the sustainable environment development issue of Asian economies.

The organization of the paper is structured as follows: Sect. 1 is designed for introduction and in Sect. 2, dynamism of Asian economies is portrayed. It is followed by Sect. 3, a succinct review of literature. Section 4 illustrates data sources and econometric methodology. Empirical results and their interpretations are analyzed in Sect. 5. In the final section conclusion and policy implications are drawn.

\section{Dynamism Of Asian Economies}

The World Bank defines economy for the current fiscal year 2021 based on per capita GNl; $<\mathbf{\$ 1 , 0 3 5}$ to low-income, $\$ 1,036$ - $\$ 4,045$ to lower middle-income, $\$ 4,046$-\$12,535 to upper middle-income, and > \$12,535 to high-income economies (World Bank 2019). As Asian upper and lower middle income and lower income economies if taken separately enclose a small number of countries, we have organized these three income categories as developing economies following World Bank definition. Therefore, most of the economies of Asia are developing economies with few exceptions. The country by GDP per capita scenario provided in Appendix I, also demonstrates that other than China, Japan, India, South Korea, Indonesia, Saudi Arabia, Turkey, Taiwan, Thailand and Iran, the countries follow the comparable GDP per capita scenario.

The dynamism of Asian economies (economies considered for this study is listed in Appendix II) lies within the fact that most of the economies can be portrayed as developing, albeit there is disparity amongst them. On the one hand, the continent contains one of the most economically developed nations of the world, Japan. On the other hand, it includes the poorest countries like Afghanistan, Cambodia, and Nepal. There are also regional varieties among Asian economies. According to the World Bank category 2019, the largest part of Southwest Asia clubs in one of the middle-income categories, including high-income economies i.e., Israel, Kuwait, Qatar, and the United Arab Emirates. Economies of North and Central Asia are predominantly low-income economies apart from Russia (World Bank 2019). The South Asia region mostly falls in lower-middle-income economic category. The most affluent side of the continent is East Asia.

Furthermore, countries in Asia are following the trends of rapid urbanization and industrialization compared to the rest of the world though a bulk of the populace are still occupied in agricultural activities. The trade-related interdependence of economies grew considerably during the late 20th century. Energy consumption (per capita) in Asia is lower than the world standard except for the oil-producing economies. China is the largest producer of energy and the largest $\mathrm{CO}_{2}$ emitter, simultaneously the leading investor in renewable energy as well. As emissionrelated issues have a trans-boundary effect, we have taken the whole Asian sample to measure wellbeing.

The study focused on this group of economies for some specific reasons. There has been an unanticipated growing demand for energy in low- and middle-income countries since the last two decades (Culver, 2017). Most of the Asian economies fall within this group. This phenomenon requires more significant investigation as more energy consumption leads to greater emission (Baek \& Kim, 2013; Alam et. al, 2011; Sharma, 2011; Pao, Yu, \& Yang, 2011 and Sadorsky, 2014) that will risk human wellbeing. For the sustainability of the environment $\mathrm{CO}_{2}$ emission and wellbeing studies need special attention for the Asian economies. Against the above circumstances, the study focuses on measuring the environmental wellbeing of Asian economies with other predictors i.e., real GDP per capita, exports as percentage of GDP, percentage of urban population.

\section{Literature Review}

\subsection{Carbon intensity of wellbeing (CIWB) and Economic Development}

The scholars termed the link between $\mathrm{CO}_{2}$ emissions and human wellbeing as the carbon intensity of wellbeing (CIWB) or Ecological Intensity of human wellbeing (EIWB) that measures environmental and human wellbeing simultaneously (Jorgenson, 2014; Dietz et al., 2012). There

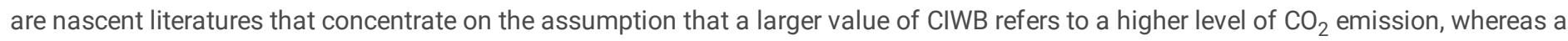
lesser value denotes a lower level of $\mathrm{CO}_{2}$ emission (Jorgenson, 2014; Jorgenson \& Dietz, 2015). Studies of Dietz et al. (2009), Dietz \& Jorgenson (2013), and Jorgenson \& Dietz (2015) concentrates on the wide-ranging ecological intensity of wellbeing context as well. In their opinion, it is a ratio of environmental pressure to human wellbeing which is operationalized taking the ratio between per capita $\mathrm{CO}_{2}$ emission and average life expectancy indicators. The (CIWB) concentrates on sustainable development issues by joining the environmental and human wellbeing indicator together into one indicator. 
The study on the link between $\mathrm{CO}_{2}$ emission and economic development receives substantial consideration, however, a very limited degree of attention has been paid to the relationship between $\mathrm{CO}_{2}$ emissions and wellbeing indicators by emphasizing economic development (Knight \& Rosa, 2011). Moreover, most studies concentrate on single or broad indicators, i.e., life expectancy, human development index, life satisfaction, apart from few exceptions (O’Neill, Fanning, Lamb, \& Steinberger, 2018). There are studies that have concentrated on fundamental socio-technical changes that convey message to keep economic development, energy use and emissions within the boundary of ecological wellbeing (Lamb, 2016; Sulkowski \& White, 2016).

The relationship between economic development (growth) and environmental wellbeing is elucidated utilizing the Environmental Kuznets Curve (EKC) theory of Grossman and Krueger in 1995 (Press \& Journal, 2010). There are innumerable studies that deal with EKC hypothesis (e.g., Hamit-Haggar, 2012; Friedl \& Getzner, 2003; Al-Mulali, Saboori, \& Ozturk, 2015 and Sharmin \& Tareque, 2020). These studies have postulated that each economy is unique in terms of underlying aspects that impels the link involving human and environmental wellbeing and development. There is not known studies that concentrate on social wellbeing indicators (i.e., water, sanitation, life expectancy issues) applying EKC hypothesis on Asian economies.

\subsection{Economic development, urbanization, energy consumption and CIWB}

Rosa et al. (2010) establish that the impact of economic development on CIWB is a sustainability issue concerning the links among environmental, social and economic growth. Givens (2015) has identified that level of economic development and urbanization are linked with higher CIWB. This study also finds that a healthy urban development could lower the Carbon intensity of wellbeing. Dietz \& Jorgenson (2013) investigate population dynamics with affluence as a stimulator of environmental impacts to show human-environment connections. Another study (Sadorsky, 2015) examined the effect of urbanization on $\mathrm{CO}_{2}$ emissions in 7 emerging economies. The study of Sharmin \& Tareque (2018) have investigated that growth exploits energy consumption which is the reason behind the increase of $\mathrm{CO}_{2}$ emissions that hinders the quality of environment in Bangladesh. This study has found along with growth and energy use; urbanization, industrialization is the catalyst behind $\mathrm{CO}_{2}$ emission as well.

Urbanization is increasing energy consumption as found from the study of A. K. Jorgenson, Rice, \& Clark, (2010) and their findings suggest

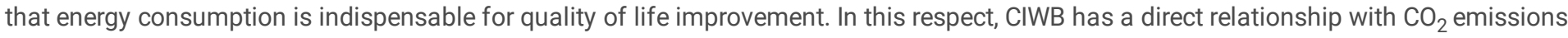
and quality of life. Corresponding to that, it has a positive correlation with $\mathrm{CO}_{2}$ emissions (A. K. Jorgenson, Auerbach, \& Clark, 2014). In connection with environmental and other human wellbeing issues, Liu et al. (2010) found that most arable land is transformed to urbanization and it is harmful to those countries that have a high depletion rate but a low potential for sustainable development. The study of Mazur (2011) has found that increased energy and electricity use is vital for poor nations to improve wellbeing and is not associated with improved wellbeing of industrialized nations. Some studies are in favor of using renewable energy instead of non-renewable energy to sustain environmental and human wellbeing (e.g., Baek \& Kim, 2013; Al-Mulali, 2014; Sharif, Raza, Ozturk, \& Afshan, 2019; Sharmin, 2021). In their view, more use of renewable enrgy might have poitive impact on overall wellbeing indicators and could reduce ecological footprint.

From the above-mentioned empirical evidence, it is discernible that a large amount of literature investigates the connection linking economic activities and its impact on the environment. But there is a paucity of studies that concentrate on social and human wellbeing indicators (i.e. water, sanitation, life expectancy, health issues) along with environmental issues applying EKC hypothesis on Asian economies. This study aims to contribute to above-mentioned less explored areas of literature.

\section{Data Sources And Econometric Methodology}

\subsection{Data}

The scales of analysis of this study are country level. The study uses data on 47 Asian countries for the period 1990-2019 for panel analyses. Annual data of all study variables are collected from the World Development Indicators (WDI) database (World Bank, 2019). The list of Asian countries is available in Appendix I. China and Hong Kong is treated as separate nations in this study as World Bank provides separate datasets for them. The description of the included variables can be found in Table 1.

Table-1. Variable Description 


\begin{tabular}{|ll|}
\hline Variables & Measurements \\
\hline $\mathrm{CO}_{2}$ emissions & per capita in metric tons \\
\hline Life Expectancy & total life expectancy at birth \\
\hline Carbon Intensity of Well-being (CIWB) per capita & Ratio between $\mathrm{CO}_{2}$ emissions and life expectancy \\
\hline GDP per capita & Constant U.S dollars (2010) \\
\hline Exports & $\%$ of GDP \\
\hline Urban population & $\%$ of total \\
\hline Improved water source, urban & $\%$ of urban population with access \\
\hline Improved sanitation facilities, urban & $\%$ of urban population with access \\
\hline Improved water source & $\%$ of population with access \\
\hline Improved sanitation facilities & $\%$ of population with access \\
\hline Fertility rate, total & births per woman \\
\hline Prevalence of HIV, total & $\%$ of population ages 15-49 \\
\hline Note: Author's compilation & \\
\hline
\end{tabular}

All variables included in this study are transformed into natural logarithms. Log transformation would help to measure the elasticity of estimated coefficients that would represent the percentage change in the dependent variable (CIWB) for a percentage in the independent variable (York et al., 2003).

\subsection{Dependent Variable}

The measure of the carbon intensity of wellbeing (CIWB) is a ratio between $\mathrm{CO}_{2}$ emissions per capita and life expectancy at birth which is consistent with others (e.g., Dietz et al., 2012; A. K. Jorgenson, 2014; A. K. Jorgenson \& Givens, 2015). But one complicacy arises with a ratio as a measure when the range and variability differs substantially and creates the problem of the numerator or denominator dominance. In our dataset, the coefficient of variation of $\mathrm{CO}_{2}$ emissions per capita is 0.903 , and the range is $0.097-5.46$. The coefficient of variation of life expectancy is 0.092 , and the range is $50.33-84.93$. To solve the issue of dominance, a constant is added to the numerator, which shifts the mean with changing the variance, thereby help to balance the coefficient of variation of our numerator and denominator (e.g., Givens, 2015; Dietz et al., 2012). For this study, the coefficient of variation of life expectancy and $\mathrm{CO}_{2}$ emissions per capita has been made equivalent by adding 7.915466 to $\mathrm{CO}_{2}$ emissions per capita. Further, it was multiplied by 100 to scale the ratio. The carbon intensity of well-being (CIWB) is measured as:

$\mathrm{CIWB}=((\mathrm{CO} 2$ emissions per capita +7.915466$) /$ life expectancy $) \times 100$

Therefore, the CIWB measures the human wellbeing obtained for each unit of $\mathrm{CO}_{2}$ emitted; a lower CIWB is more likely expected than a high CIWB for making the economic development and other social indicators sustainable.

\subsection{Independent Variable}

The independent variables of interest are the real GDP per capita, exports as a percentage of GDP, percentage of the urban population. Following Givens (2015), the percent of the urban population with access to an improved water source and improved sanitation facilities as well as a percent of the total population with access to an improved water source and improved sanitation facilities are taken in this study to address further urban social attributes. Another two variables are incorporated; expectation to have a considerable impact on overall health and $\mathrm{CO}_{2}$ emissions. And those are the total fertility rate and the prevalence of HIV (A. K. Jorgenson \& Rice, 2016).

\subsection{Model Specification}

Following Givens (2015), the functional form of the tested model is given as: 


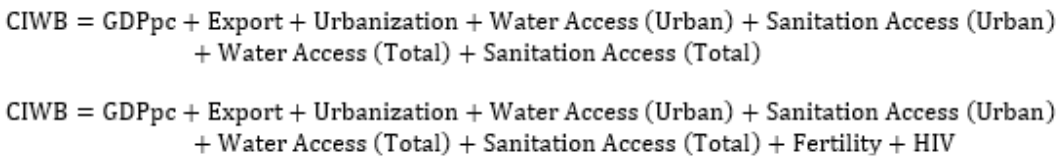

\subsection{Model Estimation Technique}

The study uses the time-series cross-sectional Prais-Winsten regression model with panel-corrected standard errors (PCSEs). The PraisWinsten regression model is suggested by Beck \& Katz (1995) because the Feasible Generalized Least Squares (FGLS) method ${ }^{[1]}$ produces incorrect standard errors. In STATA 14, PCSEs assume by default that the disturbances are heteroskedastic and contemporaneously correlated across panels. First-order autocorrelation, AR(1), within panels is corrected for estimation (Sweidan \& Alwaked, 2016), and a twoway fixed-effect technique is employed to control for country-specific and time-specific disturbances. To check the robustness of the estimation, the pooled OLS (Driscoll-Kraay standard errors, which are more robust in the presence of heteroscedasticity and autocorrelation up to some lags in the error term) method is also applied.

\section{Empirical Findings And Their Interpretations}

\subsection{Descriptive Statistics}

It is fundamental to understand the underlying characteristics of studied variables before any adoption of estimation techniques in econometric analysis. Table 2 presents the descriptive analysis of the studied variables from 1990-2019 under investigation.

\begin{tabular}{|lllllll|}
\hline Table-2 & & & & & & \\
\hline Summary Statistics & & & & & \\
\hline Variables & Count & Mean & Standard deviation & Min & \\
\hline Carbon Intensity of Well Being (CIWB) & 1363 & 2.519776 & .1364384 & 2.232054 & 3.003861 \\
\hline GDP per capita (constant 2010 US\$) & 1315 & 8.300426 & 1.464898 & 5.247104 & 11.15166 \\
\hline Exports of goods and services (\% of GDP) & 1249 & 3.523849 & .9479813 & -5.225669 & 5.433695 \\
\hline Urban population (\% of total population) & 1410 & 3.882175 & .5586387 & 2.180869 & 4.60517 \\
\hline Drinking water services, urban (\% of urban population) & 683 & 4.541347 & .0924525 & 3.901719 & 4.60517 \\
\hline Drinking water services (\% of population) & 843 & 4.449669 & .2300012 & 3.324025 & 4.60517 \\
\hline Sanitation services, urban (\% of urban population) & 682 & 4.399729 & .2358965 & 3.387306 & 4.60517 \\
\hline Sanitation services (\% of population) & 835 & 4.289753 & .4357813 & 2.298918 & 4.60517 \\
\hline Fertility rate, total (births per woman) & 1363 & .9743254 & .422774 & -.10425 & 2.15246 \\
\hline Prevalence of HIV, total (\% of population ages 15-49) & 928 & -1.849881 & .7544196 & -2.302585 & .7419373 \\
\hline Source: Author's calculation & & & & & \\
\hline
\end{tabular}

The mean carbon intensity of wellbeing (CIWB) of the panel is 2.519, and the mean GDP per capita of the samples is 8.3 US\$. The average percentage of people living in urban areas is 3.882 , and the mean exports percentage is 3.523 . The mean percentage of services (water and sanitation) of the urban and total population is almost same and all those are around 4.45 . The mean fertility rate of the panel is below one, and the mean prevalence of HIV among people of reproductive age group is -1.849 . 


\begin{tabular}{|c|c|c|c|c|c|c|c|c|c|c|}
\hline \multicolumn{11}{|l|}{ Table-3 } \\
\hline \multicolumn{11}{|c|}{ Correlation Matrix } \\
\hline Variables & CIWB & GDPpc & Exports & Urbanization & $\begin{array}{l}\text { Drinking } \\
\text { water } \\
\text { (\% of } \\
\text { Urban) }\end{array}$ & $\begin{array}{l}\text { Drinking } \\
\text { water } \\
\text { (\% of } \\
\text { Pop) }\end{array}$ & $\begin{array}{l}\text { Sanitation } \\
\text { (\% of } \\
\text { Urban) }\end{array}$ & $\begin{array}{l}\text { Sanitation } \\
\text { (\% of } \\
\text { Pop) }\end{array}$ & $\begin{array}{l}\text { Fertility } \\
\text { Rate }\end{array}$ & $\begin{array}{l}\text { HIV } \\
\text { Prevalence } \\
\text { (\% of Pop) }\end{array}$ \\
\hline CIWB & 1.00 & & & & & & & & & \\
\hline GDPpc & $-0.63^{\star \star \star}$ & 1.00 & & & & & & & & \\
\hline Exports & $-0.21^{\star \star \star}$ & $0.40^{\star \star \star}$ & 1.00 & & & & & & & \\
\hline Urbanization & $-0.47^{\star \star \star}$ & $0.82^{\star \star \star}$ & $0.31^{\star \star \star}$ & 1.00 & & & & & & \\
\hline $\begin{array}{l}\text { Drinking } \\
\text { water (\% of } \\
\text { Urban) }\end{array}$ & $-0.35^{\star \star \star}$ & $0.50^{\star \star \star}$ & $0.44^{\star \star \star}$ & $0.50^{\star \star \star}$ & 1.00 & & & & & \\
\hline $\begin{array}{l}\text { Drinking } \\
\text { water (\% of } \\
\text { Pop) }\end{array}$ & $-0.45^{\star \star \star}$ & $0.56^{\star \star \star}$ & $0.31^{\star \star \star}$ & $0.67^{\star \star \star}$ & $0.88^{\star \star \star}$ & 1.00 & & & & \\
\hline $\begin{array}{l}\text { Sanitation } \\
\text { (\% of Urban) }\end{array}$ & $-0.31^{\star \star \star}$ & $0.60^{\star \star \star}$ & $0.32^{\star \star \star}$ & $0.64^{\star \star \star}$ & $0.55^{\star \star \star}$ & $0.54^{\star \star \star}$ & 1.00 & & & \\
\hline $\begin{array}{l}\text { Sanitation } \\
\text { (\% of Pop) }\end{array}$ & $-0.41^{\star \star \star}$ & $0.63^{\star \star \star}$ & $0.27^{\star \star \star}$ & $0.74^{\star \star \star}$ & $0.58^{\star \star \star}$ & $0.71^{\star \star \star}$ & $0.89^{\star \star \star}$ & 1.00 & & \\
\hline Fertility Rate & $0.45^{\star \star \star}$ & $-0.48^{\star \star \star}$ & $-0.24^{\star \star \star}$ & $-0.46^{\star \star \star}$ & $-0.58^{\star \star \star}$ & $-0.58^{\star \star \star}$ & $-0.43^{\star \star \star}$ & $-0.48^{\star \star \star}$ & 1.00 & \\
\hline $\begin{array}{l}\text { HIV } \\
\text { Prevalence } \\
\text { (\% of Pop) }\end{array}$ & -0.06 & $-0.08^{*}$ & 0.07 & $-0.27^{\star \star \star}$ & -0.06 & $-0.23^{\star \star \star}$ & -0.04 & $-0.26^{\star \star \star}$ & $-0.22^{\star \star \star}$ & 1.00 \\
\hline
\end{tabular}

The correlation matrix of the studied variables is reported in Table 3. The table shows that GDP per capita and urbanization are negatively correlated with CIWB. The urbanization is positively correlated with GDP per capita, where the fertility rate is negatively correlated with GDP per capita. Basic citizen services, e.g., drinking water and sanitation, are also positively correlated with GDP per capita and urbanization. But those services are negatively correlated with CIWB.

\subsection{Panel Unit Root test}




\begin{tabular}{|c|c|c|c|c|}
\hline \multicolumn{5}{|l|}{ Table-4 } \\
\hline \multicolumn{5}{|l|}{ Panel Unit Root Tests } \\
\hline \multirow[t]{2}{*}{ Variables } & \multicolumn{2}{|l|}{ Without trend } & \multicolumn{2}{|l|}{ With trend } \\
\hline & ADF-Fisher & PP-Fisher & ADF-Fisher & PP-Fisher \\
\hline GDP per capita & $89.2607(0.5022)$ & $89.2607(0.5022)$ & $290.0031(0.000)$ & $290.0031(0.000)$ \\
\hline$\Delta$ GDP per capita & $715.8310(0.000)$ & $715.8310(0.000)$ & $640.0251(0.000)$ & $640.0251(0.000)$ \\
\hline Exports (\% of GDP) & $181.6066(0.000)$ & $181.6066(0.000)$ & $163.2781(0.000)$ & $163.2781(0.000)$ \\
\hline$\Delta$ Exports (\% of GDP) & $1102.3679(0.000)$ & $1102.3679(0.000)$ & $954.2279(0.000)$ & $954.2279(0.000)$ \\
\hline Urbanization & $1016.2471(0.000)$ & $1016.2471(0.000)$ & $420.4920(0.000)$ & $420.4920(0.000)$ \\
\hline$\Delta$ Urbanization & $197.3791(0.000)$ & $197.3791(0.000)$ & $367.4158(0.000)$ & $367.4158(0.000)$ \\
\hline Drinking water services, urban & $347.0541(0.0000)$ & $347.0541(0.0000)$ & $754.9256(0.0000)$ & $682.8383(0.0000)$ \\
\hline$\Delta$ Drinking water services, urban & $779.3366(0.0000)$ & $779.3366(0.0000)$ & $757.9251(0.0000)$ & $757.9251(0.0000)$ \\
\hline Drinking water services, pop & $791.1844(0.0000)$ & $791.1844(0.0000)$ & $451.8477(0.0000)$ & $451.8477(0.0000)$ \\
\hline$\Delta$ Drinking water services, pop & $613.3418(0.0000)$ & $613.3418(0.0000)$ & $865.7791(0.0000)$ & $865.7791(0.0000)$ \\
\hline Sanitation water services, urban & $668.5889(0.0000)$ & $668.5889(0.0000)$ & $626.0461(0.0000)$ & $553.9587(0.0000)$ \\
\hline$\Delta$ Sanitation water services, urban & $523.1803(0.0000)$ & $523.1803(0.0000)$ & $523.8915(0.0000)$ & $451.8042(0.0000)$ \\
\hline Sanitation water services, pop & $774.4264(0.0000)$ & $774.4264(0.0000)$ & $876.2206(0.0000)$ & $876.2206(0.0000)$ \\
\hline$\Delta$ Sanitation water services, pop & $710.5767(0.0000)$ & $710.5767(0.0000)$ & $678.2597(0.0000)$ & $678.2597(0.0000)$ \\
\hline
\end{tabular}

Two panel unit root tests with and without trend were conducted to check the stationary property of the datasets and presented in Table 4. Both ADF-Fisher and PP-Fisher tests confirmed that all variables become stationary at levels except GDP per capita. The GDP per capita becomes stationary after first differencing. Therefore, the order of the integration of GDP per capita is I(1) and all other variables are I(0).

\subsection{Panel Cointegration}

\begin{tabular}{|lll|}
\hline Table-5 & & \\
\hline Kao Test for Panel Cointegration & & \\
\hline Ho: No cointegration & & \\
\hline Ha: All panels are cointegrated & & \\
\hline & Statistic & P-value \\
\hline Modified Dickey-Fuller t & 0.476 & 0.317 \\
\hline Dickey-Fuller t & 3.7523 & 0.0001 \\
\hline Augmented Dickey-Fuller t & 3.0764 & 0.001 \\
\hline Unadjusted modified Dickey-Fuller t & 0.3562 & 0.3608 \\
\hline Unadjusted Dickey-Fuller t & 3.6498 & 0.0001 \\
\hline
\end{tabular}

To test the long-run relationship of the studied variables, the study has conducted a Kao test for testing panel cointegration (Table 5). Out of the five, three statistics of the Kao test have rejected the null hypothesis of no cointegration. This outcome leads us to conclude that the variables have a long-run relationship.

\subsection{Panel Regression}


Table 6

presents the detailed findings for the estimated models using Prais-Winsten estimator and pooled OLS estimator. Both models contain all 47 countries included in the analyses and controls for the following: GDP per capita; exports as a percent of GDP; urban population as a percent of the total population; the percent of the urban population with access to an improved water source; the percent of the urban population with access to improved sanitation facilities; the percent of the total population with access to an improved water source; and the percent of the total population with access to improved sanitation facilities. Regression outputs report the regression coefficients, significance level, panel corrected standard errors, R-squared statistic, and the number of observations.

\begin{tabular}{|c|c|c|}
\hline \multicolumn{3}{|l|}{ Effects of studied variables on Carbon Intensity of Wellbeing } \\
\hline & Prais-Winsten Estimator & Pooled OLS Estimator \\
\hline GDP per capita (constant 2010 US\$) & $0.276^{\star \star \star}(0.0224)$ & $0.276^{\star \star \star}(0.0272)$ \\
\hline Square of GDP per capita & $-0.0216^{* \star *}(0.00122)$ & $-0.0216^{\star * \star}(0.00147)$ \\
\hline Exports of goods and services (\% of GDP) & $0.00653^{\star}(0.00297)$ & $0.00653^{\star \star \star}(0.00149)$ \\
\hline Urban population (\% of total population) & $0.129^{\star \star \star}(0.00865)$ & $0.129^{\star \star \star}(0.00714)$ \\
\hline Drinking water services, urban (\% of urban population) & $-0.0856^{*}(0.0340)$ & $-0.0856(0.0606)$ \\
\hline Sanitation services, urban (\% of urban population) & $-0.000345(0.0157)$ & $-0.000345(0.0228)$ \\
\hline Drinking water services (\% of population) & $-0.191 * \star \star(0.0168)$ & $-0.191 * \star \star(0.0230)$ \\
\hline Sanitation services (\% of population) & $-0.0160(0.00830)$ & $-0.0160(0.0102)$ \\
\hline Constant & $2.518 * \star \star(0.156)$ & $2.518 * \star \star(0.290)$ \\
\hline Observations & 606 & 606 \\
\hline $\mathrm{R}^{2}$ & 0.472 & 0.472 \\
\hline
\end{tabular}

Table 6 presents the detailed findings for the estimated models using Prais-Winsten estimator and pooled OLS estimator. Both models contain all 47 countries included in the analyses and controls for the following: GDP per capita; exports as a percent of GDP; urban population as a percent of the total population; the percent of the urban population with access to an improved water source; the percent of the urban population with access to improved sanitation facilities; the percent of the total population with access to an improved water source; and the percent of the total population with access to improved sanitation facilities. Regression outputs report the regression coefficients, significance level, panel corrected standard errors, R-squared statistic, and the number of observations.

In the Prais-Winsten and pooled OLS estimator models, GDP per capita is positive and statistically significant in the total sample of countries. Both estimator models exhibit the same coefficient for GDP per capita, confirming the robustness of the model. In both estimation techniques, the environmental Kuznets hypothesis is sustained that describes the overall relationship between GDP per capita and CIWB. Since GDP per capita is the indicator for the level of development of an economy for the linear term, so having a positive and significant association between GDP per capita and CIWB is undesirable. If the CIWB increases with the increase of per capita GDP, then it may threaten economic sustainability in the long run as lower CIWB is desirable and is an attribute of human wellbeing. On the other hand, a negative coefficient for the square of the GDP per capita resulting an inverted U-shaped pattern which is envisaged by the Kuznets theory. It postulates that a boost up in economic affluence from the lowest levels to a mid-level tends to increase the CIWB, but past a turning point, carbon intensity per unit wellbeing decreases which is desirable.

Exports as a percent of GDP correspond to the connection to the world economy, is significant as well as the urban population is positive and significant for the sample of countries. In terms of the findings of specific interest, urban population access to an improved water source and total population access to an improved water source has consistently negative and significant effects on both estimation models. But the urban population access to improved sanitation and total population access to improved sanitation is negative and insignificant in models. 


\begin{tabular}{|c|c|c|}
\hline \multicolumn{3}{|l|}{ Table-7 } \\
\hline \multicolumn{3}{|l|}{ Effects of studied variables on Carbon Intensity of Well-being } \\
\hline & Prais-Winsten Estimator & Pooled OLS Estimator \\
\hline GDP per capita (constant 2010 US\$) & $0.149^{* \star \star}(0.0166)$ & $0.149^{\star \star \star}(0.0239)$ \\
\hline Square of GDP per capita & $-0.0138^{\star \star \star}(0.000937)$ & $-0.0138^{\star \star \star}(0.00136)$ \\
\hline Exports of goods and services (\% of GDP) & $0.0117^{\star \star \star}(0.00226)$ & $0.0117^{\star \star \star}(0.00215)$ \\
\hline Urban population (\% of total population) & $0.123^{\star \star \star}(0.00615)$ & $0.123^{\star \star \star}(0.00636)$ \\
\hline Drinking water services, urban (\% of urban population) & $-0.176^{*}(0.0543)$ & $-0.176^{*}(0.0755)$ \\
\hline Sanitation services, urban (\% of urban population) & $0.0365(0.0204)$ & $0.0365(0.0282)$ \\
\hline Drinking water services (\% of population) & $-0.186^{* \star *}(0.0203)$ & $-0.186^{* * \star}(0.0204)$ \\
\hline Sanitation services (\% of population) & $-0.0291^{\star \star}(0.0111)$ & $-0.0291^{\star \star}(0.0137)$ \\
\hline Fertility rate, total (births per woman) & $-0.00612(0.0108)$ & $-0.00612(0.00813)$ \\
\hline Prevalence of HIV, total (\% of population ages 15-49) & $-0.0173^{\star \star \star}(0.00358)$ & $-0.0173^{\star \star \star}(0.00374)$ \\
\hline Constant & $3.286^{\star \star \star}(0.212)$ & $3.286^{\star \star \star}(0.319)$ \\
\hline Observations & 462 & 462 \\
\hline $\mathrm{R}^{2}$ & 0.539 & 0.539 \\
\hline Standard errors in parentheses. ${ }^{*} p<0.0$ & 0.001 & \\
\hline
\end{tabular}

Two additional control variables were taken in the estimation procedure with the expectation that they might have an impact on the overall wellbeing of human and the environment, and those are total fertility rate and the prevalence of HIV in the population of 15-49 year olds (Table 7). This table shows the findings for the estimated models using Prais-Winsten estimator and pooled OLS estimator. Both models contain all 47 countries included in the analyses and control variables are the same as Table 6 . Regression outputs report the regression coefficients, significance level, panel corrected standard errors, R-squared statistic, and the number of observations. The outputs of Table 7 are not so different from the obtained findings of the previous table (Table 6). Here, the results also support the environmental Kuznets hypothesis.

Exports as a percent of GDP, is significant as well as the urban population is positive and significant for the sample countries. Specifically, urban population access to an improved water source and total population access to an improved water source has consistently negative and significant effects on both estimation models. But the urban population access to improved sanitation and total population access to improved sanitation is negative and insignificant in models. Both the fertility rate and the prevalence of HIV are interlinked with a decrease of the CIWB in the case of Asian countries showing no harmful impact. The findings are also desirable to lower CIWB.

\section{Discussions}

If we further go deeper into the findings we have got from the two models, the results are consistent and follow theoretical explanation. The assumption of EKC hypothesis is straightforward that an increase in per capita GDP (affluence) will decrease environmental stress and enhance sustainability therefore wellbeing. Our findings support EKC hypothesis. The findings of this study for Asian economies as a whole is supporting 'economic and ecological modernization' theory and opposing the 'treadmills of production' theory which is different from the findings of Dietz et al. (2012) and Knight \& Rosa (2011). The reason might be unlike their studies we have incorporated issues like social wellbeing indicators (i.e. water, sanitation, fertility rate, prevalence of HIV etc.) while applying EKC hypothesis. The factors other than per capita GDP could play a substantial role in well-being and sustainability, as suggested by both the above-mentioned studies is working here. The study of Rice (2008) put forward that in comparison to developed economies, developing economies have a higher level of marginal utility of environmental utilization. As from figure in Appendix I, shows the GDP per capita of Asian economies are mostly developing economies other that few developed economies. This could be another reason that the findings supporting 'economic and ecological modernization' theory and 'human ecology' theory for Asian economies. 
The findings of this study are also compatible with the findings of A. K. Jorgenson (2014) as long as the African economies are concerned though in present decades, their growth-CIWB relationship is becoming slightly unsustainable. However, considering Asian economies, the study found that with the increase in GDP per capita CIWB increases. This finding diverges from our finding that with the increase in growth, CIWB decreases as established by EKC theory. The rationale might be that the study of Jorgenson did not incorporated all the Asian economies and only concentrates on GDP per capita and CIWB whereas, our study includes other indicators also to see the relationship. The growth-CIWB association for North America, Europe and Oceania is positive because this region is generally pooled to the high-income economies and it is possible that they are burning more fossil fuels to ensure economic growth. Steinberger et al. (2012) have found that high-income countries are responsible for more carbon emissions and Fang et al. (2019) also address that G-20 countries are also following an unsustainable path for growth. These findings resonate with the study of Akenji et.al, (2016) and they have found that the richest economies should reduce their expenditure whereas, the poorest economies could increase their growth to reduce the ecological pressure.

Due to limitations in data availability, the study uses unbalanced data on 47 Asian countries for the period 1990-2019 for panel analyses. Moreover, the inclusion and exclusion of different variables might show the dissimilar outcome.

\section{Conclusion And Policy Implications}

This study investigates the economic, social and environmental wellbeing issues by measuring the carbon intensity of wellbeing (CIWB) of Asian economies. 'Economic and ecological modernization' theory is of the opinion that for sustainability, economic development is fundamental and 'human ecology' theory encompasses a wider perspective and views of wellbeing considering human development and sustainable climate conditions. On the other hand, the 'treadmills of production' theory and political economy theory negates the necessity of economic development for sustainability. The findings of the paper are well matched with the view of the 'Economic and ecological modernization' theory that postulates that with the increase in economic growth environmental quality will be restored as well as with 'human ecology' perspective that is in favor of wellbeing including health and climate conditions. It is evident from the findings of this study that a negative coefficient for the square of the GDP per capita resulting an inverted U-shaped pattern and also from the other social indicators.

Employing Prais-Winsten and pooled OLS estimator, in both the estimation models urban population access to an improved water source and total population access to improved water source has consistently negative and significant effects on CIWB. The fertility rate and prevalence of HIV also pose no threat to CIWB. These findings as a whole demonstrate that social and human wellbeing indicators of the Asian economies are sustainable to this moment as they are lowering CIWB. These results confirm and relate to the study of Givens (2015). On the other hand, GDP per capita, exports as a percent of GDP and urban population is significant and positive for CIWB in the case of Asian countries, which pose a challenge for the sustainability issue as they are increasing CIWB. In this regard, the Asian economies should choose better urbanization and economic growth policies that ensure the sustainability of the human and environmental factors and reduces the impact on CIWB. More specifically, the use of renewable energy for the decarburization of a country's economy is very crucial with environmental governance and better institutional quality for sustainability. Future studies should take into account the feminization of environmental issues in wellbeing research.

\section{Declarations}

Ethical Approval-Not applicable.

Consent to Participate-Not applicable.

Consent to Publish-All authors have read and approved the manuscript to publish with this journal.

Authors Contributions-Conceptualization, writing, referencing and final format: Mowshumi Sharmin. Data analysis and result: Sima Rani Dey. Supervision, proofreading and review: Dr. Md Tariqul Islam

Funding-There is no finding source

Competing Interests-The authors declare that they have no competing interests.

Availability of data and materials- Data is available from the corresponding author upon request.

\section{References}

1. Akenji L, Bengtsson M, Bleischwitz R, Tukker A, Schandl H (2016) Ossified materialism: introduction to the special volume on absolute reductions in materials throughput and emissions. J Clean Prod 132:1-12. https://doi.org/10.1016/j.jclepro.2016.03.071

Page $11 / 14$ 
2. Al-Mulali U (2014) Investigating the impact of nuclear energy consumption on GDP growth and CO2 emission: A panel data analysis. Prog Nucl Energy 73:172-178

3. Al-Mulali U, Saboori B, Ozturk I (2015) Investigating the environmental Kuznets curve hypothesis in Vietnam. Energy Policy 76:123-131

4. Alam MJ, Begum IA, Buysse J, Rahman S, Van Huylenbroeck G (2011) Dynamic modeling of causal relationship between energy consumption, CO2 emissions and economic growth in India. Renew Sustain Energy Rev 15(6):3243-3251

5. Baek J, Kim HS (2013) Is economic growth good or bad for the environment? Empirical evidence from Korea. Energy Econ 36:744-749

6. Beck N, Katz JN (1995) What to do and not to do. The American Political Science Review, 89(3), 634-647. Retrieved from http://journals.cambridge.org/abstract_S0003055400000083

7. Bubolz MM, Sontag MS (2008) Human Ecology Theory. In Sourcebook of Family Theories and Methods (pp. 419-450). https://doi.org/10.1007/978-0-387-85764-0_17

8. Culver LC (2017) A framework for understanding the role for natural gas in reducing energy poverty. Tech. rep, Stanford: Natural Gas Initiative, Stanford University

9. D'Albis H, Bonnet F (2018) Inequalities in life expectancy and the global welfare convergence. Econ Lett 168:49-51

10. Dietz T, Jorgenson A (2013) Structural human ecology: new essays in risk, energy, and sustainability. Washington State University Press

11. Dietz T, Rosa EA, York R (2009) Environmentally efficient well-being: rethinking sustainability as the relationship between human wellbeing and environmental impacts. Human Ecology Review, 114-123

12. Dietz T, Rosa EA, York R (2012) Environmentally efficient well-being: Is there a Kuznets curve? Appl Geogr 32(1):21-28

13. Fang J, Lau CKM, Lu Z, Wu W, Zhu L (2019) Natural disasters, climate change, and their impact on inclusive wealth in G20 countries. Environ Sci Pollut Res 26(2):1455-1463. https://doi.org/10.1007/s11356-018-3634-2

14. Friedl B, Getzner M (2003) Determinants of CO2 emissions in a small open economy. Ecol Econ 45(1):133-148

15. Givens JE (2015) Urbanization, slums, and the carbon intensity of well-being: implications for sustainable development. Human Ecology Review 22(1):107-128

16. Group WB (2017) World development indicators 2017. World Bank

17. Hamit-Haggar M (2012) Greenhouse gas emissions, energy consumption and economic growth: A panel cointegration analysis from Canadian industrial sector perspective. Energy Econ 34(1):358-364

18. Hill TD, Jorgenson A (2018) Bring out your dead!: A study of income inequality and life expectancy in the United States, $2000-2010$. Health Place 49:1-6

19. Hu Y, Jia G, Pohl C, Feng Q, He Y, Gao H, ... Feng J (2015) Improved monitoring of urbanization processes in China for regional climate impact assessment. Environ Earth Sci 73(12):8387-8404. https://doi.org/10.1007/s12665-014-4000-4

20. Jordan SJ, Hayes SE, Yoskowitz D, Smith LM, Summers JK, Russell M, Benson WH (2010) Accounting for natural resources and environmental sustainability: linking ecosystem services to human well-being. ACS Publications

21. Jorgenson AK (2014) Economic development and the carbon intensity of human well-being. Nature Climate Change 4(3):186-189

22. Jorgenson AK, Auerbach D, Clark B (2014) The (de-) carbonization of urbanization, 1960-2010. Clim Change 127(3-4):561-575

23. Jorgenson AK, Clark B (2013) The relationship between national-level carbon dioxide emissions and population size: an assessment of regional and temporal variation, 1960-2005. PloS One 8(2):e57107

24. Jorgenson AK, Dietz T (2015) Economic growth does not reduce the ecological intensity of human well-being. Sustain Sci 10(1):149156

25. Jorgenson AK, Givens J (2015) The Changing Effect of Economic Development on the Consumption-Based Carbon Intensity of WellBeing, 1990-2008. PLOS ONE 10(5):e0123920. https://doi.org/10.1371/journal.pone.0123920

26. Jorgenson AK, Rice J (2016) Slum Prevalence and Health in Developing Countries: Sustainable Development Challenges in the Urban Context. Sustain Dev 24(1):53-63. https://doi.org/10.1002/sd.1606

27. Jorgenson AK, Rice J, Clark B (2010) Cities, slums, and energy consumption in less developed countries, 1990 to 2005 . Organization Environment 23(2):189-204

28. Jorgenson A, Rice J, Clark B (2012) Assessing the temporal and regional differences in the relationships between infant and child mortality and urban slum prevalence in less developed countries, 1990-2005. Urban Studies 49(16):3495-3512

29. Knight KW, Rosa EA (2011) The environmental efficiency of well-being: A cross-national analysis. Soc Sci Res 40(3):931-949

30. Lamb WF (2016) Which countries avoid carbon-intensive development? J Clean Prod 131:523-533.

https://doi.org/10.1016/j.jclepro.2016.04.148

Page 12/14 
31. Liu YS, Wang JY, Long HL (2010) Analysis of arable land loss and its impact on rural sustainability in Southern Jiangsu Province of China. J Environ Manage 91(3):646-653

32. Mazur A (2011) Does increasing energy or electricity consumption improve quality of life in industrial nations? Energy Policy 39(5):2568-2572

33. O’Neill DW, Fanning AL, Lamb WF, Steinberger JK (2018) A good life for all within planetary boundaries. Nature Sustainability 1(2):88-95

34. Pao H-T, Yu H-C, Yang Y-H (2011) Modeling the CO2 emissions, energy use, and economic growth in Russia. Energy 36(8):5094-5100

35. Parks RW (1967) Efficient Estimation of a System of Regression Equations when Disturbances are Both Serially and Contemporaneously Correlated. J Am Stat Assoc 62(318):500. https://doi.org/10.2307/2283977

36. Parris TM, Kates RW (2003) Characterizing and measuring sustainable development. Annu Rev Environ Resour 28(1):559-586

37. Press TMIT, Journal TQ (2010) Economic Growth and the Environment Author (s): Gene M. Grossman and Alan B. Krueger Published by : The MIT Press Stable URL : http://www.jstor.org/stable/2118443. Gene, 110(2), 353-377

38. Rice J (2008) Material consumption and social well-being within the periphery of the world economy: An ecological analysis of maternal mortality. Soc Sci Res 37(4):1292-1309. https://doi.org/10.1016/j.ssresearch.2008.05.006

39. Rosa EA, Diekmann A, Dietz T, Jaeger CC (2010) Human footprints on the global environment: Threats to sustainability. MIT Press

40. Sachs JD (2015) The age of sustainable development. Columbia University Press

41. Sadorsky P (2014) The effect of urbanization on CO2 emissions in emerging economies. Energy Econ 41:147-153. https://doi.org/10.1016/j.eneco.2013.11.007

42. Sharif A, Raza SA, Ozturk I, Afshan S (2019) The dynamic relationship of renewable and nonrenewable energy consumption with carbon emission: a global study with the application of heterogeneous panel estimations. Renewable Energy 133:685-691

43. Sharma SS (2011) Determinants of carbon dioxide emissions: empirical evidence from 69 countries. Appl Energy 88(1):376-382

44. Sharmin M (2021) Relationship of Renewable and Non-Renewable Energy Utilization with CO2 Emission of Bangladesh. Energy Economics Letters 8(1):49-59

45. Sharmin M, Tareque M (2018) Econometric Analysis of the Effect of Economic Globalization, Energy Intensity, Urbanization, Industrialization and Growth on co 2 Emissions of Bangladesh. Managing Global Transitions: International Research Journal, 16(4)

46. Sharmin M, Tareque M (2020) Sustainable Growth-Environment Nexus in the Context of Four Developing Asian Economies: A Panel Analysis. International Research Journal 18(3):237-256

47. Sirgy MJ (2012) The psychology of quality of life: Hedonic well-being, life satisfaction, and eudaimonia, vol 50. Springer Science \& Business Media

48. Smith LM, Case JL, Smith HM, Harwell LC, Summers JK (2013) Relating ecoystem services to domains of human well-being: Foundation for a US index. Ecol Ind 28:79-90

49. Steinberger JK, Roberts T, Peters J, G. P., \& Baiocchi G (2012) Pathways of human development and carbon emissions embodied in trade. Nature Climate Change 2(2):81-85. https://doi.org/10.1038/nclimate1371

50. Sulkowski A, White DS (2016) A happiness Kuznets curve? Using model-based cluster analysis to group countries based on happiness, development, income, and carbon emissions. Environ Dev Sustain 18(4):1095-1111. https://doi.org/10.1007/s10668-015-9689-z

51. Summers JK, Smith LM, Harwell LC, Buck KD (2017) The development of a human wellbeing index for the United States. Quality of Life and Quality of Working Life. Rijeka: In-Tech Publishing, 97-135

52. Summers JK, Smith LM, Harwell LC, Case JL, Wade CM, Straub KR, Smith HM (2014) An index of human well-being for the US: a TRIO approach. Sustainability 6(6):3915-3935

53. Sweidan OD, Alwaked AA (2016) Economic development and the energy intensity of human well-being: Evidence from the GCC countries. Renew Sustain Energy Rev 55:1363-1369. https://doi.org/10.1016/j.rser.2015.06.001

54. Talberth J, Cobb C, Slattery N (2007) The genuine progress indicator 2006. Oakland, CA: Redefining Progress, 26

55. Wainger LA, Price EW (2004) Evaluating quality of life, economic vulnerabilities, and drivers of ecosystem change. Environ Monit Assess 94(1-3):69-84

56. World Bank (2019) World Development Indicators (WDI)

57. York R, Rosa EA, Dietz T (2003) Footprints on the earth: The environmental consequences of modernity. Am Sociol Rev 68(2):279-300

\section{Supplementary Files}

This is a list of supplementary files associated with this preprint. Click to download.

Page 13/14 
- Appendix.docx

Page 14/14 